\title{
Insights into the draft genome sequence of bioactives-producing Bacillus thuringiensis DNG9 isolated from Algerian soil-oil slough
}

\author{
Mohamed Seghir Daas ${ }^{1,2+}$, Albert Remus R. Rosana ${ }^{3 \dagger}$, Jeella Z. Acedo ${ }^{3}$, Malika Douzane $^{2}$, Farida Nateche ${ }^{4}$,
} Salima Kebbouche-Gana ${ }^{1}$ and John C. Vederas ${ }^{3^{*}}$

\begin{abstract}
Bacillus thuringiensis is widely used as a bioinsecticide due to its ability to form parasporal crystals containing proteinaceous toxins. It is a member of the Bacillus cereus sensu lato, a group with low genetic diversity but produces several promising antimicrobial compounds. B. thuringiensis DNG9, isolated from an oil-contaminated slough in Algeria, has strong antibacterial, antifungal and biosurfactant properties. Here, we report the $6.06 \mathrm{Mbp}$ draft genome sequence of $B$. thuringiensis DNG9. The genome encodes several gene inventories for the biosynthesis of bioactive compounds such as zwittermycin A, petrobactin, insecticidal toxins, polyhydroxyalkanoates and multiple bacteriocins. We expect the genome information of strain DNG9 will provide another model system to study pathogenicity against insect pests, plant diseases, and antimicrobial compound mining and comparative phylogenesis among the Bacillus cereus sensu lato group.
\end{abstract}

Keywords: Bacillus thuringiensis, Genome sequencing, Bioinformatics, Secondary metabolites, Bacteriocin, Zwittermycin a

\section{Introduction}

Bacillus thuringiensis is a rod-shaped, Gram-positive bacterium that has been isolated from a variety of ecological niches including soil, aquatic environments, and dead insects, among many others [1]. B. thuringiensis is known for its utility as a bioinsecticide due to its ability to produce parasporal crystals that contain protein toxins (e.g. Cry proteins, also called $\delta$-endotoxins) during its sporulation and stationary growth phase [2]. These protein toxins have also been successfully introduced to genetically modified crops, as exemplified in Bt corn, rendering these crops resistant to specific insect pests [3]. The protein toxins have been shown to be safe to plants, beneficial insects, and mammals due to the absence of specific receptors that are normally only found in the target organisms $[4,5]$. The potential of $B$. thuringiensis to serve

\footnotetext{
* Correspondence: john.vederas@ualberta.ca

${ }^{+}$Mohamed Seghir Daas and Albert Remus R Rosana contributed equally to this work.

${ }^{3}$ Department of Chemistry, University of Alberta, Edmonton, AB T6G 2G2, Canada

Full list of author information is available at the end of the article
}

as an alternative to chemical insecticides has driven the discovery of new $B$. thuringiensis strains that may lead to the identification of novel protein toxins with potential use in pest management $[1,6]$. Aside from the insecticidal properties of $B$. thuringiensis, it has also been reported to exhibit antibacterial, antifungal, antibiofilm and emulsifying activities [7, 8]. In general, the Bacillus species are known to be rich sources of antimicrobial compounds [9-12]. For B. thuringiensis, its antibacterial effects can be attributed to a wide range of compounds including bacteriocins and lipopeptides [13]. On the other hand, its antifungal activity has been attributed to the production of compounds such as zwittermycin, chitinase, and lipopeptides [7]. In this study, the whole genome sequence of $B$. thuringiensis DNG9 that was isolated from an oil-contaminated slough in Baraki-Algiers, Algeria was determined. This strain was chosen for sequencing due to its strong antimicrobial and emulsifying properties. It was the aim of this work to obtain a better understanding of the observed bioactivities based on the genes encoded in its genome. 


\section{Organism information}

\section{Classification and features}

Bacillus thuringiensis DNG9 was isolated from an oil-contaminated soil slough in Baraki-Algiers, Algeria. The samples were serially diluted in water, heat-shocked at $80{ }^{\circ} \mathrm{C}$ for $30 \mathrm{~min}$, spread onto Luria Bertani (LB) agar and incubated at $35{ }^{\circ} \mathrm{C}$ for $24 \mathrm{~h}$. Strain DNG9, like the majority of other reported $B$. thuringiensis strains, are Gram-positive, aerobic to facultative anaerobic bacterium [14]. The cells are rod-shaped, flagellated (Fig. 1a) and endospore-forming (Fig. 1b, c). The bacterium has a growth temperature range from 10 to $48{ }^{\circ} \mathrm{C}$ with an optimal growth at $28-35^{\circ} \mathrm{C}$ [15] and $\mathrm{pH} 4.9-8.0$ with an optimal pH of $7.0[16,17]$. It produces parasporal bodies during the stationary phase of its growth cycle (Fig. 1c), which is consistent with the three cry genes predicted from its genome. Two homologs of cry 41 and one homolog of cry6 genes were predicted from the genome of DNG9 using the BtToxin Scanner server [18]. The key features of DNG9 are summarized in Table 1.

Thirteen Bacillus strains and DNG9 were chosen for phylogenetic analysis. The chosen species represent the members of B. cereus sensu lato supergroup [19]. This includes the type strains $B$. thuringiensis Berliner ATCC $10792^{\mathrm{T}}$, B. cereus ATCC $14579^{\mathrm{T}}$ and B. anthracis AMES
Ancestor. The 16S rRNA gene sequence from the type strain B. subtilis subsp. subtilis ATCC $6051^{\mathrm{T}}$ [20] was selected as an outgroup. The maximum likelihood method was used to construct the phylogenetic tree shown in Fig. 2. The phylogenetic tree supports the placement of strain DNG9 within the $B$. thuringiensis group together with the type strain B. thuringiensis Berliner ATCC $10792^{\mathrm{T}}$.

\section{Genome sequencing information}

\section{Genome project history}

The project information and associated MIGS (Minimum Information about a Genome Sequence) 2.0 compliance [21] are summarized in Table 2. This bacterium was selected for sequencing as it was determined to be one of the most promising strains for discovery of compounds with strong antibacterial (Fig. 1d), antifungal and biosurfactant abilities (Additional file 1: Figure S1). The availability of the draft genome of DNG9 may contribute to the evolution and comparative genomics studies of the $B$. cereus sensu lato group. Furthermore, future investigations on its genome-encoded bioactive metabolites may be pursued. This work provided a standard draft genome and the assembled contigs have been deposited in public repositories. The PGAP- and JGI-IM- annotated genomes were deposited to the DDBJ/ENA/GenBank
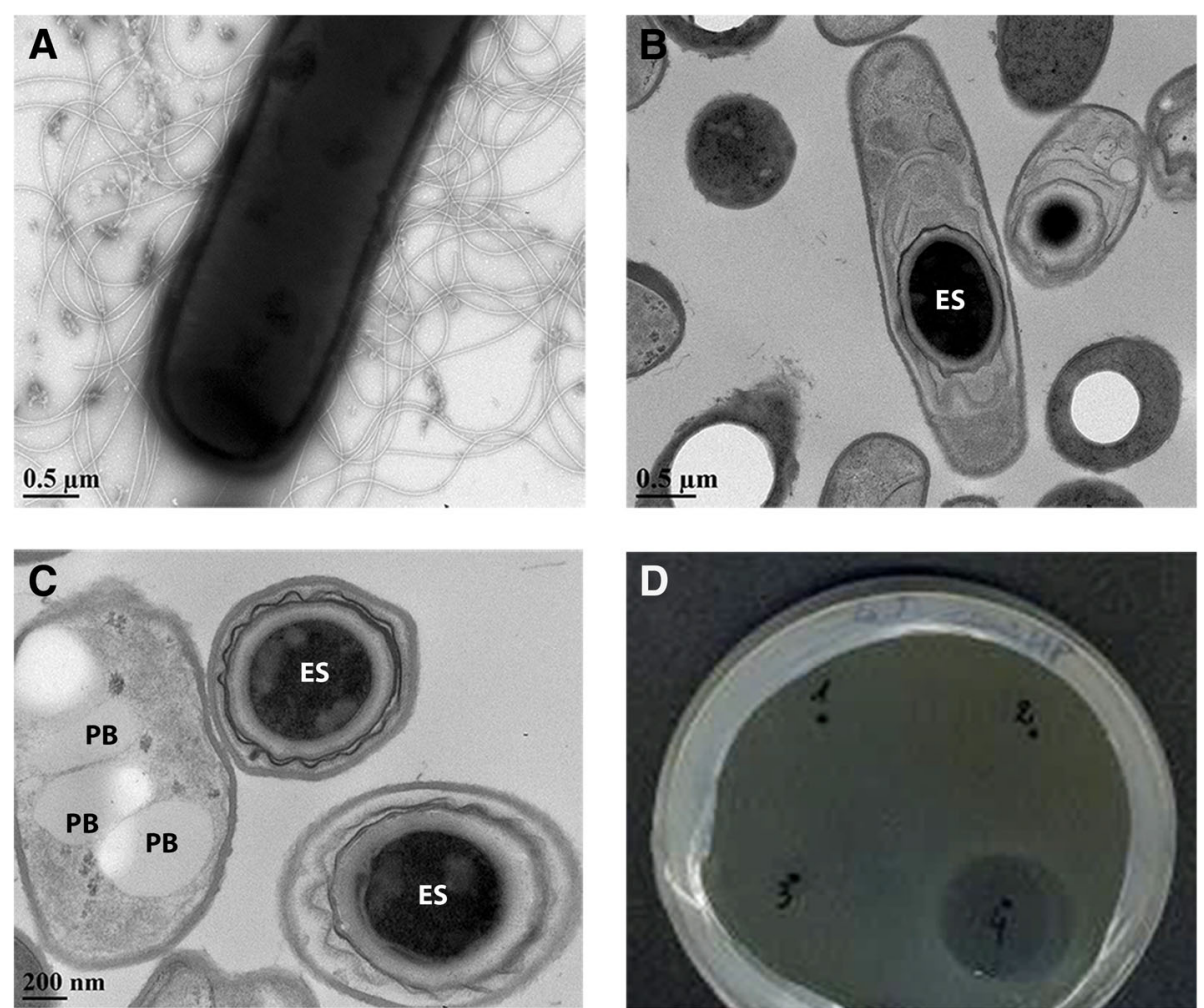

Fig. 1 General characteristics of Bacillus thuringiensis DNG9. Transmission electron micrograph (TEM) of DNG9 showing a flagellated cell, b subcentral endospore, ES, and $\mathbf{c}$ parasporal bodies, PB. $\mathbf{d}$ Spot-on-lawn assay showing the activity of DNG9 supernatant (labelled as 4) against indicator strain Lactococcus lactis subsp. cremoris HP 
Table 1 Classification and general features of Bacillus thuringiensis strain DNG9 according to the MIGS recommendation [19]

\begin{tabular}{|c|c|c|c|}
\hline MIGS ID & Property & Term & Evidence code \\
\hline & Classification & Domain Bacteria & TAS [53] \\
\hline & & Phylum Firmicutes & TAS [16] \\
\hline & & Class Bacilli & TAS $[54,55]$ \\
\hline & & Order Bacillales & $\operatorname{TAS}[42,56]$ \\
\hline & & Family Bacillaceae & $\operatorname{TAS}[42,57]$ \\
\hline & & Genus Bacillus & TAS $[41,42]$ \\
\hline & & Species Bacillus thuringiensis & $\operatorname{TAS}[42,58]$ \\
\hline & & Strain DNG9 & \\
\hline & Gram stain & Positive & IDA \\
\hline & Cell shape & Rod & IDA \\
\hline & Motility & Motile & IDA \\
\hline & Sporulation & Spore (Subcentral) & IDA \\
\hline & Temperature range & $10^{\circ} \mathrm{C}-48^{\circ} \mathrm{C}$ & TAS [15] \\
\hline & Optimum temperature & $28^{\circ} \mathrm{C}-35^{\circ} \mathrm{C}$ & TAS [15] \\
\hline & pH range; Optimum & $4.9-8.0 ; 7.0$ & $\operatorname{TAS}[16,17]$ \\
\hline & Carbon source & Glucose & NAS \\
\hline MIGS-6 & Habitat & Soil & NAS \\
\hline MIGS-6.3 & Salinity & Salt tolerant & TAS [59] \\
\hline MIGS-22 & Oxygen requirement & Aerobic, & IDA \\
\hline MIGS-15 & Biotic relationship & Free-living & IDA \\
\hline MIGS-14 & Pathogenicity & Insect pathogen & TAS [60] \\
\hline MIGS-4 & Geographic location & Algeria & NAS \\
\hline MIGS-5 & Sample collection & February 13, 2013 & NAS \\
\hline MIGS-4.1 & Latitude & $36^{\circ} 40^{\prime} 9^{\prime \prime} \mathrm{N}$ & NAS \\
\hline MIGS-4.2 & Longitude & $3^{\circ} 5^{\prime} 43^{\prime \prime} \mathrm{E}$ & NAS \\
\hline MIGS-4.4 & Altitude & $22 \mathrm{~m}$ & NAS \\
\hline
\end{tabular}

aEvidence codes: IDA Inferred from Direct Assay, TAS Traceable Author Statement (i.e., a direct report exists in the literature), NAS Non-traceable Author Statement (i.e., not directly observed for the living, isolated sample, but based on a generally accepted property for the species, or anecdotal evidence). These evidence codes are from the Gene Ontology project [61]

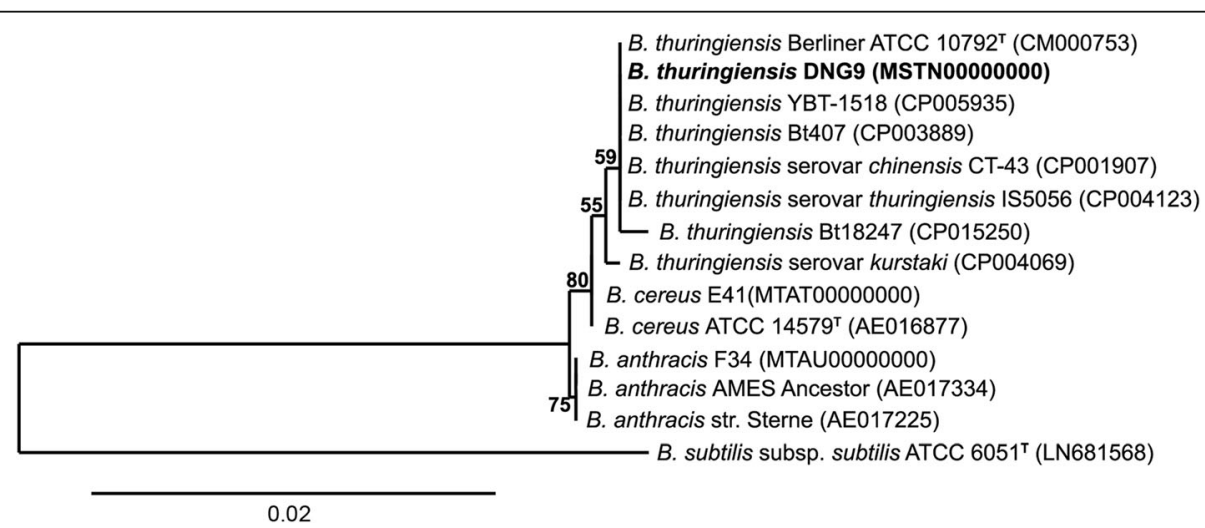

Fig. 2 Maximum likelihood phylogeny of Bacillus thuringiensis DNG9 165 rRNA gene isolated from Algerian soil-oil slough. Nucleic acid sequences were aligned using Geneious and the tree compiled using RaxML. Numbers above the branches refer to bootstrap values. The tree was rooted using Bacillus subtilis subsp. subtilis ATCC $6051^{\top}$. Type strains are indicated with ${ }^{\top}$. All strains represent sequenced genomes. Scale bar indicates 2 nucleotide substitution for each 10 nucleotide sequences. Accession numbers of publicly available sequences are given in brackets 
Table 2 Project information

\begin{tabular}{lll}
\hline MIGS ID & Property & Term \\
\hline MIGS 31 & Finishing quality & Draft genome \\
MIGS-28 & Libraries used & Illumina paired-end \\
MIGS 29 & Sequencing platforms & Illumina MiSeq100 \\
MIGS 31.2 & Fold coverage & $317 \times$ \\
MIGS 30 & Assemblers & CLC Genomic Workbench 7.5.2 \\
MIGS 32 & Gene calling method & GeneMarkS, Prodigal \\
& Locus Tag & BVF97 \\
& Genbank ID & MSTN00000000 \\
& GenBank Date of Release & 9-Mar-17 \\
& GOLD ID & Ga0180945 \\
& BIOPROJECT & PRJNA359364 \\
MIGS 13 & Source Material Identifier & DNG9 \\
& Project relevance & Agricultural, Biotechnological \\
\hline
\end{tabular}

databases under accession numbers MSTN00000000 and Ga0180945, respectively.

\section{Growth conditions and genomic DNA preparation}

Genomic DNA was isolated from a combined 16-h grown single colony isolate and a two $\mathrm{mL}$ 16-h grown liquid culture (150 rpm) from LB agar and LB broth, respectively. Total nucleic acid was extracted using the method described previously [22]. Briefly, cells were harvested at $500 \times \mathrm{g}$ for $2 \mathrm{~min}$ and resuspended in $100 \mu \mathrm{l} 1 \times$ TE buffer (100 mM Tris- $\mathrm{HCl}, 50 \mathrm{mM}$ EDTA, $\mathrm{pH}$ 8.0). Cell slurry was sequentially treated with $20 \mathrm{mg} / \mathrm{ml}$ lysozyme $\left(37{ }^{\circ} \mathrm{C}, 30 \mathrm{~min}\right), 2 \mathrm{mg} / \mathrm{ml}$ proteinase $\mathrm{K}\left(56{ }^{\circ} \mathrm{C}\right.$, $30 \mathrm{~min}$ ) and $0.5 \mathrm{mg} / \mathrm{ml} \mathrm{RNase} \mathrm{A}\left(37^{\circ} \mathrm{C}, 30 \mathrm{~min}\right)$. The sphaeroplast suspension was lysed with $500 \mu \mathrm{l}$ cell breakage buffer $(0.4 \%$ sodium dodecyl sulfate, $0.5 \%$ $\mathrm{N}$-lauroyl sarcosine, $0.5 \%$ Triton X-100, $50 \mathrm{mM}$ Tris, $100 \mathrm{mM}$ EDTA, pH 8.0), $400 \mu \mathrm{l}$ phenol and $150 \mu \mathrm{l}$ glass beads $(0.5 \mathrm{~mm}$ dia, Sartorius, Germany). The slurry was vortexed for $1 \mathrm{~min}$ and rested for $1 \mathrm{~min}$ on ice, for a total of 10 cycles, and finally clarified at $13000 \times \mathrm{g}$ for $5 \mathrm{~min}$ at room temperature. The aqueous layer was repeatedly extracted with equal volume of phenol, followed by phenol:chloroform (1:1) and finally with chloroform: isoamyl alcohol (24:1). The DNA was precipitated with $0.1 \times 3 \mathrm{M}$ sodium acetate $\mathrm{pH} 5.2$ and $2.5 \times$ absolute ethanol, washed with $70 \%$ ethanol and resuspended in $10 \mathrm{mM}$ Tris buffer, $\mathrm{pH}$ 8.0. Quantity and quality were assessed using Qubit 2.0 fluorometry (Qiagen) and agarose gel electrophoresis, respectively.

\section{Genome sequencing and assembly}

The genome of Bacillus thuringiensis DNG9 was sequenced at The Applied Genomic Core, Department of Biochemistry, University of Alberta using Illumina paired-end sequencing platform and Nextera XT DNA library kit (Illumina, USA). Whole genome sequencing was performed in duplicates using the MiSeq Reagent kit v2. Sequencing of $250 \mathrm{bp}$ paired-end modules gathered $3.69 \mathrm{M}$ reads, which provided an average coverage of $317 \times$ resulting in 38 contigs. De novo assembly of the 6,057,430 bp paired-end sequences was created using CLC Genomics Worksbench v 7.5.2. (CLC bio, Aarhus, Denmark).

\section{Genome annotation}

Gene prediction was performed using four automated genome annotation pipelines: (1) the NCBI Prokaryotic Genome Annotation Pipeline (PGAP) [23] using GeneMarkS+ and best-placed reference protein set; (2) the Joint Genome Institute - Integrated Microbial Genomes and Microbiomes (JGI-IMG/M) pipeline [24] utilizing Prodigal gene caller [25]; (3) the Rapid Annotation using Subsystem Technology (RAST) v2.0 server [26]; and (4) the Bacterial Annotation System (BASys) server [27]. CRISPR repeats were predicted by using CRISPRfinder [28]. The draft genome of DNG9 was aligned with the type strain B. thuringiensis Berliner ATCC $10792^{\mathrm{T}}$ closed genome to generate a single scaffold using Contiguator v2 [29] and Multi-Draft based Scaffolder (MEDUSA) [30]. A chromosome map was generated from the single scaffold using BASys automated pipeline [27] and viewed using CGViewer [31].

Species was established using genome-wide Average Nucleotide Identity (gANI) metric and alignment fraction (AF) calculated within the JGI-IMG/M server using the Microbial Species Identifier (MiSI) calculator [32]. Strain was established using the Genome-to-Genome Distance Calculator (GGDC) 2.1 server employing digital DNA:DNA hybridization $(\mathrm{dDDH})$ and DNA G $+\mathrm{C}$ content [33].

\section{Genome properties}

The draft genome of DNG9 is $6,057,430$ bp with $34.9 \%$ GC content, similar to the genomes of other Bacillus thuringiensis strains [34-36], and contained 38 scaffolds with $\mathrm{N}_{50}$ of $347,259 \mathrm{bp}$. A total of 135 RNA genes and 284 pseudogenes were annotated by IMG/M and PGAP, respectively (Table 3 ). Annotation using the DOE-JGI IMG/M pipeline revealed 6109 total coding sequences of which 4463 have functional predictions. Conversely, RAST annotation pipeline predicted 6055 coding sequences; NCBI-PGAP revealed 6213 coding genes; and lastly, BASys annotated 6102 coding sequences. The 4463 coding sequences predicted in IMG/M pipeline were placed in 25 general clusters of orthologous (COG) functional gene catalogs. The distribution of these protein-coding genes based on COG function is listed in Table 4. The $6.06 \mathrm{Mbp}$ draft genome map of DNG9, as aligned against the type strain $B$. thuringiensis Berliner ATCC 10792, is presented in Fig. 3. 
Table 3 Genome statistics

\begin{tabular}{lll}
\hline Attribute & Value & \% of Total \\
\hline Genome size (bp) & $6,057,430$ & 100.00 \\
DNA coding (bp) & $5,053,197$ & 83.42 \\
DNA G + C (bp) & $2,107,907$ & 34.80 \\
DNA scaffolds & 38 & 100.00 \\
Total genes & 6109 & 100.00 \\
Protein coding genes & 5974 & 97.79 \\
RNA genes & 135 & 2.21 \\
Pseudo genes & 284 & 4.65 \\
Genes in internal clusters & 2024 & 33.13 \\
Genes with function prediction & 4463 & 73.06 \\
Genes assigned to COGs & 3633 & 59.47 \\
Genes with Pfam domains & 4883 & 79.93 \\
Genes with signal peptides & 284 & 4.65 \\
Genes with transmembrane helices & 1741 & 28.50 \\
CRISPR repeats & 4 & 0.07 \\
\hline
\end{tabular}

\section{Insights from the genome sequence}

B. thuringiensis DNG9 was found to be flagellated, sporulating with a subcentral endospore and producing the insecticidal parasporal bodies (Fig. 1a, b, c). These phenotypes are supported by gene inventories found in the genome of DNG9 (Fig. 3). The RAST annotation has allocated these genes into 490 subsystems, the most abundant of which are genes that are associated with amino acid and derivatives metabolism (15.5\%), followed by carbohydrate (11.7\%), and protein metabolism (7.6\%).

DNG9 was found to be most active against Lactococcus lactis subsp. cremoris HP (Fig. 1d) [37, 38], and was also active against Carnobacterium divergens LV13 [39], Salmonella. enterica Typhimurium ATCC 23564 [40], and Micrococcus sp. ATCC 700405 [41] but not against Escherichia coli JM109 [42, 43], Pseudomonas aeruginosa ATCC 14217 [42, 44], and Enterococcus faecalis 710C [45]. Conversely, DNG9 was also found to be active against the fungus Galactomyces geotrichum MUCL 28959 but not Aspergillus niger ATCC 9142 and Candida albicans ATCC 10231. The antiSMASH 4.0 server predicted that DNG9 genome carries the gene clusters

Table 4 Number of genes associated with general COG functional categories

\begin{tabular}{|c|c|c|c|}
\hline Code & Value & \%age & Description \\
\hline J & 262 & 6.38 & Translation, ribosomal structure and biogenesis \\
\hline A & 0 & 0 & RNA processing and modification \\
\hline K & 388 & 9.44 & Transcription \\
\hline L & 135 & 3.29 & Replication, recombination and repair \\
\hline B & 1 & 0.02 & Chromatin structure and dynamics \\
\hline $\mathrm{D}$ & 60 & 1.46 & Cell cycle control, Cell division, chromosome partitioning \\
\hline V & 124 & 3.02 & Defense mechanisms \\
\hline $\mathrm{T}$ & 213 & 5.19 & Signal transduction mechanisms \\
\hline M & 236 & 5.74 & Cell wall/membrane biogenesis \\
\hline N & 55 & 1.34 & Cell motility \\
\hline$U$ & 36 & 0.88 & Intracellular trafficking and secretion \\
\hline $\mathrm{O}$ & 160 & 3.89 & Posttranslational modification, protein turnover, chaperones \\
\hline C & 210 & 5.11 & Energy production and conversion \\
\hline G & 250 & 6.09 & Carbohydrate transport and metabolism \\
\hline E & 400 & 9.74 & Amino acid transport and metabolism \\
\hline $\mathrm{F}$ & 130 & 3.16 & Nucleotide transport and metabolism \\
\hline $\mathrm{H}$ & 228 & 5.55 & Coenzyme transport and metabolism \\
\hline I & 146 & 3.55 & Lipid transport and metabolism \\
\hline P & 233 & 5.67 & Inorganic ion transport and metabolism \\
\hline Q & 109 & 2.65 & Secondary metabolites biosynthesis, transport and catabolism \\
\hline $\mathrm{R}$ & 3.96 & 9.64 & General function prediction only \\
\hline S & 301 & 7.33 & Function unknown \\
\hline- & 2476 & 40.53 & Not in COGs \\
\hline
\end{tabular}

The total is based on the total number of protein coding genes in the genome 


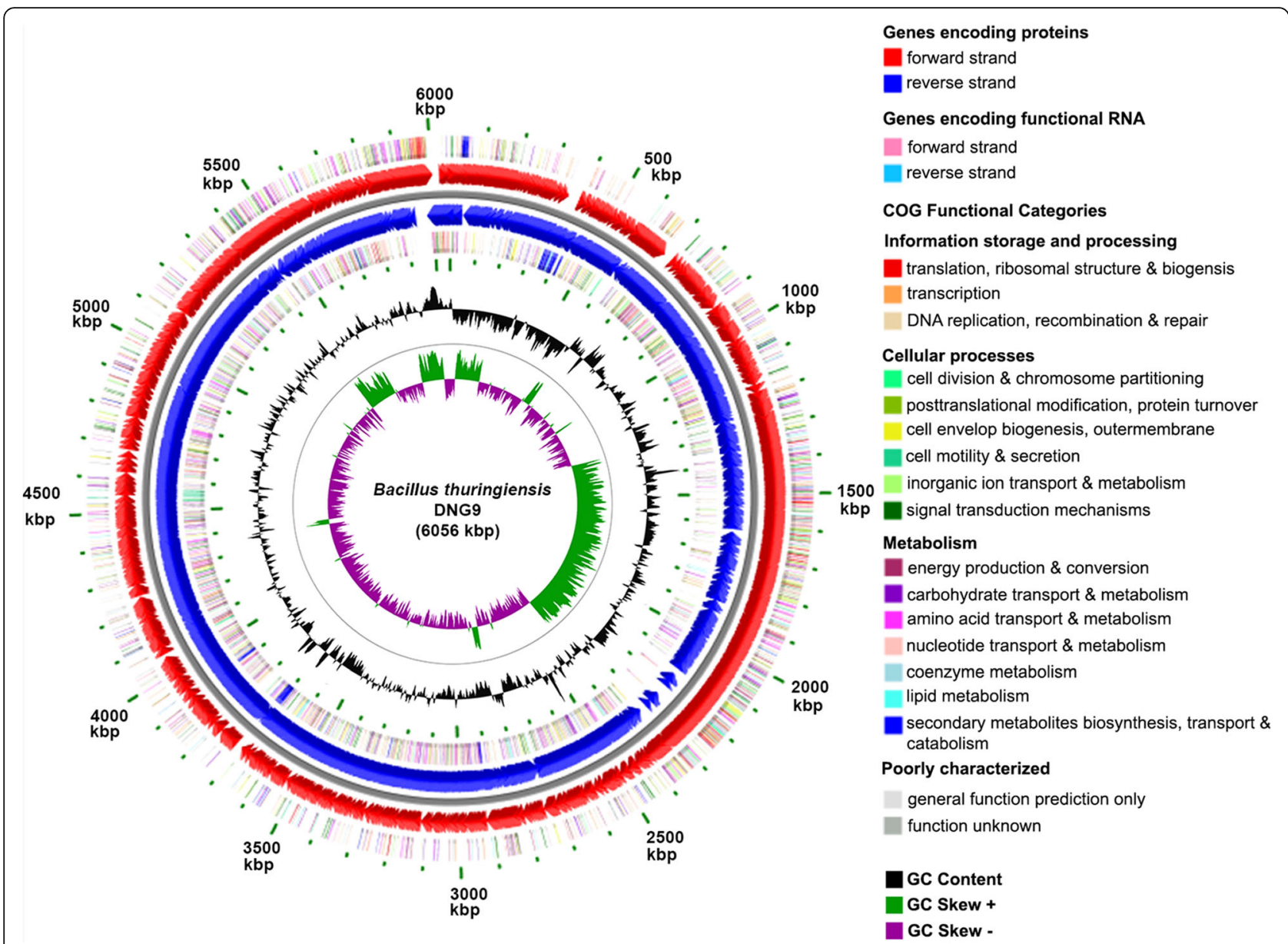

Fig. 3 Circular representation of the draft genome of DNG9 representing relevant genome features. The draft genome was aligned into one scaffold using B. thuringiensis Berliner ATCC $10792^{\top}$ genome. The outer most circle shows COG functional categories of coding regions in the clockwise direction. The lines in each concentric circle represent the position of the indicated feature; the color legend is shown to the right of the map. The second circle shows predicted coding regions transcribed on the forward (clockwise) DNA strand. The third circle shows predicted coding regions transcribed on the reverse (counterclockwise) DNA strand. The fourth circle shows COG functional categories of coding regions in the counterclockwise direction. The fifth and sixth circles show the percent GC content of the genome and the percent GC deviation (skewness) by strand, respectively

responsible for the production of several secondary metabolites including antibiotics, siderophores, and biopolymers. The genome was found to encode gene clusters with complete homology to the biosynthetic gene clusters of the antifungal compound, zwittermycin A (Fig. 4a), the iron-siderophore, petrobactin (Fig. 4b), and the bioplastic precursor, polyhydroxyalkanoates (PHAs) (Fig. 4c). The aminopolyol compound zwittermycin A was previously shown to suppress fungal-oomycete diseases in plants [46, 47], suggesting that the antifungal activity of DNG9 could be attributed to this secondary metabolite. The presence of siderophores, like petrobactin and bacillibactin, in the genome of DNG9 suggests its iron acquisition abilities. These gene clusters are not exclusive in $B$. thuringiensis but are also found in the genomes of other members of the Bacillus cereus sensu lato group [48-50]. Both antiSMASH 4.0 and BAGEL 4.0 servers also predicted a number of novel bacteriocins, mainly belonging to the class referred to as lanthipeptides (Fig. 4d, e, f). Lastly, Bt_toxin scanner revealed that $c r y$ genes encoding the insecticidal protein associated with $B$. thuringiensis is present in DNG9 genome, two homologs of cry 41 and one homolog of cry6 genes. The wide biological target range of DNG9, including its antibacterial, antifungal and insecticidal properties, could be attributed to these bioactive compounds.

The genome of DNG9 is highly similar to those of $B$. thuringiensis Berliner ATCC $10792^{\mathrm{T}}$, B. thuringiensis YBT-1518, and B. thuringiensis Bt407 based on average nucleotide identity $(>99 \%)$ and digital DNA:DNA hybridization (>95\%) (Additional file 2: Table S1), shared gene content (Fig. 5) and phylogenetic analyses of the $16 \mathrm{~S}$ rRNA gene (Fig. 2). The functional comparison of DNG9 genome composition with closely related Bacillus species 

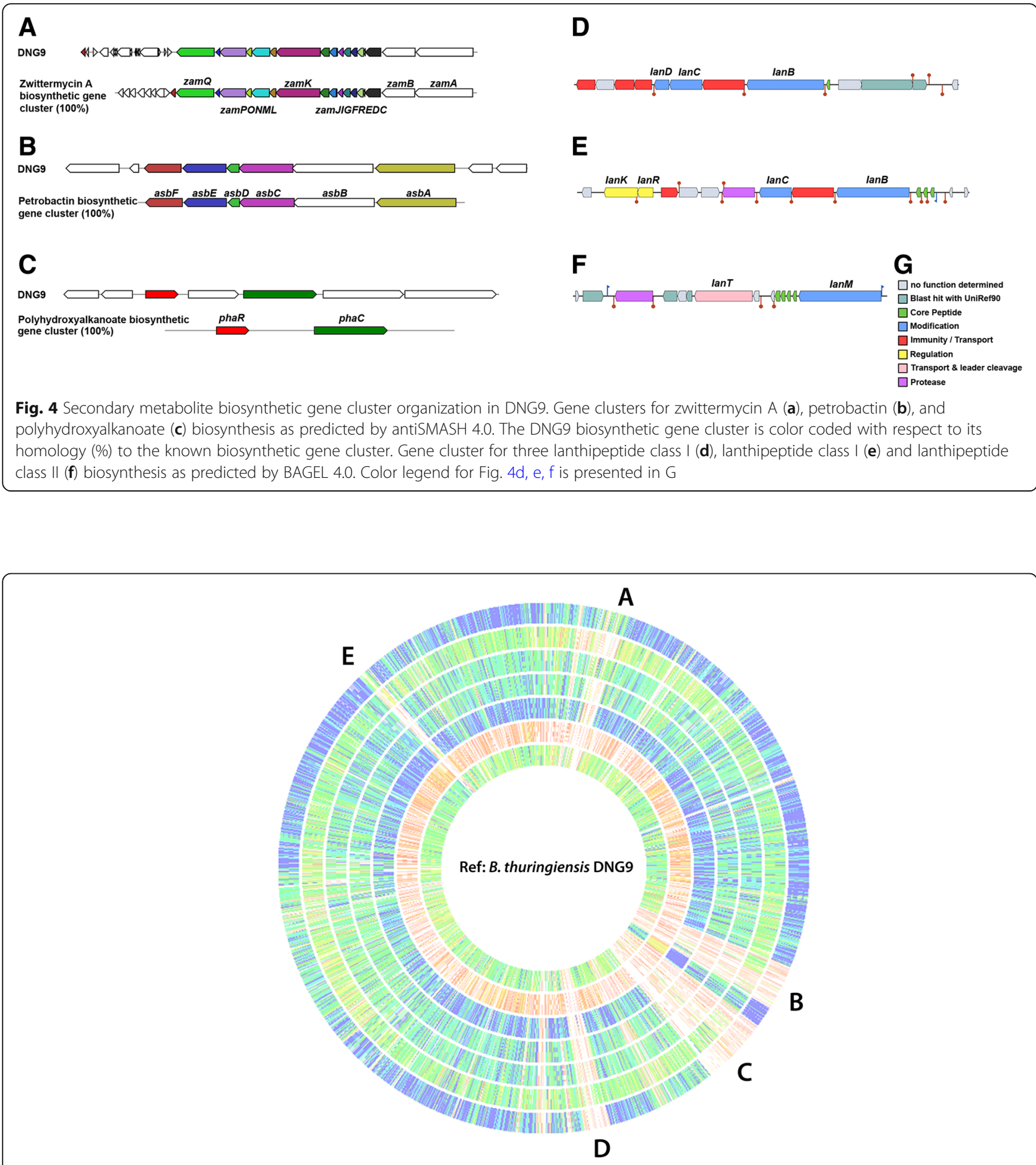

Protein sequence identity (\%)

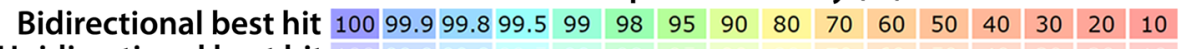

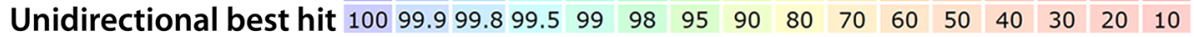

Fig. 5 Genomic comparison of DNG9 to other Bacillus sp. genomes conducted using RAST. Each track represents pair-wise BLAST comparison between the open reading frames in query genome against those in Bacillus thuringiensis DNG9 (Ref. = reference), with percentage of similarity represented with different colors shown in the legend. Regions marked in the genomic map correspond to gene number presented in Additional File 3: Table S2 ( $\mathbf{a}=250-313, \mathbf{b}=1882-2051, \mathbf{c}=2127-2374, \mathbf{d}=2785-2880, \mathbf{e}=5318-5365)$. Query genomes used in this analysis (outer ring to inner ring): B. thuringiensis Berliner ATCC $10792^{\top}$, B. anthracis F34, B. cereus ATCC 14579, B. cereus E41, B. thuringiensis YBT-1518, B. subtilis subsp. subtilis ATCC $6051^{\top}$ and B. anthracis AMES Ancestor 
(i.e. B. thuringiensis, B. cereus and B. anthracis) [19] is presented in Fig. 5. Bacillus subtilis subsp. subtilis ATCC $6051^{\mathrm{T}}$ was used as an outgroup in the map. Comparison of the genomes of DNG9 and seven closely related Bacillus species by uni- and bidirectional best BlastP implemented in RAST, cross-validated with IMG annotations and viewed in IslandViewer 4 server [51], revealed strain-specific genes that encode hypothetical proteins, which are grouped into genomic islands. (Fig. 5, Additional file 3: Table S2). These ORFs in DNG9 include a high proportion of mobile genetic elements, phage-like proteins, transposases and hypothetical proteins in five distinct genomic islands including an intact prophage in region $\mathrm{A}$ which is further supported by Phaster server [52] analysis.

\section{Conclusions}

In conclusion, here we report a $6.06 \mathrm{Mbp}$ draft genome of Bacillus thuringiensis DNG9, isolated from an oil -contaminated soil-slough in Baraki-Algeirs, Algeria. The final de novo assembly is based on $306.5 \mathrm{Mb}$ of Illumina data, which provided an average coverage of $317 \times$. The assembled genome contains 6120 coding sequences (average of 4 annotation pipelines), of which the most abundant are genes that are associated with amino acid (15.5\%), followed by carbohydrate $(11.7 \%)$, and protein metabolism $(7.6 \%)$. The antimicrobial properties of this bacterium against several Gram-positive and Gram-negative bacteria, as well as fungal phytopathogens, could be inferred in part with a number of gene inventories encoded in the draft genome. The comparative analysis with closely related bacterial genomes, alignment of the $16 \mathrm{~S}$ rRNA sequences and prediction of gene inventories for the insecticidal Cry protein biosynthesis placed strain DNG9 under Bacillus thuringiensis. This indicated that strain DNG9 could have several potential utility as an insect biocontrol agent, a fungal phytopathogen control agent, and a source of biopolymers (PHA) and antibacterial compounds. Lastly, the genome sequence of DNG9 may provide another model system to study pathogenicity against insect pests and plant diseases, and for antimicrobial compound mining and phylogenesis among Bacillus cereus sensu lato group.

\section{Additional files}

Additional file 1: Figure S1. Time-course of growth and emulsification index of $B$. thuringiensis DNG9 in LB medium at $27^{\circ} \mathrm{C}$. Time course of growth (black rhombus, [OD]) and emulsification index E24 (grey triangle, [\%]) of B. thuringiensis DNG9 during shake flask cultivations in LB medium at $27{ }^{\circ} \mathrm{C}$. The experiments were performed in triplicate and data presented in figure is average of three parallel experiments. Error bars are shown for standard deviation ( $P \leq 0.05)$. (DOCX $16 \mathrm{~kb}$ )

Additional file 2: Table S1. Average nucleotide identity (ANI) and digital DNA:DNA Hybridization (dDDH) between the genome of DNG9 and those of other Bacillales. (XLS $28 \mathrm{~kb}$ )
Additional file 3: Table S2. Gene inventory of 5 genomic islands in Bacillus thuringiensis DNG9 AND seven closely related Bacillus sp. (XLS 498 kb)

\section{Abbreviations}

AF: Alignment fraction; antiSMASH: Antibiotics \& Secondary Metabolite Analysis SHell; ATCC: American type culture collection; BASys: Bacterial annotation system; Bt corn: Bacillus thuringiensis corn; COG: Clusters of orthologous; CRISPR: Clustered Regularly Interspaced Short Palindromic Repeats; DDBJ: DNA Data Bank of Japan; dDDH: Digital DNA:DNA Hybridization; DOE: Department of Energy (United States of America); ENA: European nucleotide srchive; gANI: Genome-wide Average Nucleotide Identity; GGDC: Genome-to-Genome Distance Calculator; JGI-IMG/M: Joint Genome Institute-Integrated Microbial Genomes and Microbiomes; Mbp: Mega base pair; MeDuSa: Multi-Draft based Scaffolder; MIGS: Minimum Information about a Genome Sequence; MiSl: Microbial Species Identifier; MUCL: Mycotheque de I'Universite Catholique de Louvain; PGAP: Prokaryotic Genome Annotation Pipeline; PHA: Polyhydroxyalkanoate; RAST: Rapid Annotation using Subsystem Technology

\section{Acknowledgements}

The authors acknowledge the help of Georgina Mcintyre from The Applied Genomic Core, University of Alberta for genome sequencing and Arlene Oatway from the Advanced Microscopy Unit, Department of Biological Sciences, University of Alberta for electron microscopy analyses.

\section{Funding}

MSD was funded by Agence Universitaire de la Francophonie, France. MSD, MD, FN and SKG were supported by the National Fund for Scientific Research of Algeria. JCV was funded by the Natural Sciences and Engineering Research Council of Canada. JZA was funded by Alberta Innovates-Health Solutions. ARRR was funded by Alberta InnovatesTechnology Futures and Vanier Canada Graduate Scholarship.

\section{Authors' contributions}

The isolation of the bacterial strain was performed by MSD. The design and support of the experiments were performed by MSD, ARRR and JZA. The genome assembly, annotation and analysis were performed by ARRR. The writing of the manuscript was performed by ARRR and JZA. The editing of the manuscript was performed by MSD, ARRR, JZA, MD, FN, SKG and JCV. All authors read and approved the final manuscript.

\section{Competing interests}

The authors declare that they have no competing interests.

\section{Publisher's Note}

Springer Nature remains neutral with regard to jurisdictional claims in published maps and institutional affiliations.

\section{Author details \\ ${ }^{1}$ Valcore Laboratory, Department of Biology, University M'Hamed Bougara of Boumerdes, 35000 Boumerdes, Algeria. ${ }^{2}$ Food Technology Research Division, Institut National de la Recherche Agronomique d'Algérie, 16200, El Harrach, Algiers, Algeria. ${ }^{3}$ Department of Chemistry, University of Alberta, Edmonton, AB T6G 2G2, Canada. ${ }^{4}$ Microbiology Group, Laboratory of Cellular and Molecular Biology, Faculty of Biological Sciences, University of Science and Technology-Houari Boumediene, 16111, Bab Ezzouar, Algiers, Algeria.}

Received: 26 February 2018 Accepted: 28 September 2018 Published online: 11 October 2018

References

1. Palma L, Muñoz D, Berry C, Murillo J, Caballero P. Bacillus thuringiensis toxins: an overview of their biocidal activity. Toxins. 2014;6:3296-325.

2. Jouzani GS, Valijanian E, Sharafi R. Bacillus thuringiensis: a successful insecticide with new environmental features and tidings. App Microbiol Biotechnol. 2017;101:2691-711.

3. Hellmich RL, Hellmich KA. Use and impact of Bt maize. Nat Educ Knowl. 2012;3:4.

4. Mendelsohn M, Kough J, Vaituzis Z, Matthews K. Are Bt crops safe? Nat Biotechnol. 2003;21:1003-9. 
5. Bravo A, Likitvivatanavong S, Gill SS, Soberón M. Bacillus thuringiensis: a story of a successful bioinsecticide. Insect Biochem Mol Biol. 2011;41:423-31.

6. Pardo-Lopez L, Soberon M, Bravo A. Bacillus thuringiensis insecticidal threedomain cry toxins: mode of action, insect resistance and consequences for crop protection. FEMS Microbiol Rev. 2012;37:3-22.

7. Djenane Z, Nateche F, Amziane M, Gomis-Cebolla J, El-Aichar F, Khorf H, et al. Assessment of the antimicrobial activity and the entomocidal potential of Bacillus thuringiensis isolates from Algeria. Toxins. 2017:9:139.

8. Deepak R, Jayapradha R. Lipopeptide biosurfactant from Bacillus thuringiensis pak2310: a potential antagonist against Fusarium oxysporum. J Mycol Med. 2015;25:W15-24

9. Stein T. Bacillus subtilis antibiotics: structures, syntheses and specific functions. Mol Microbiol. 2005;56:845-57.

10. Cochrane SA, Vederas JC. Lipopeptides from Bacillus and Paenibacillus spp.: a gold mine of antibiotic candidates. Med Res Rev. 2016;36:4-31.

11. Daas MS, Rosana AR, Acedo JZ, Nateche F, Kebbouche-Gana S, Vederas JC, et al. Draft genome sequences of Bacillus cereus E41 and Bacillus anthracis F34 isolated from Algerian salt lakes. Genome Announce. 2017;5:e00383-17.

12. Daas MS, Acedo JZ, Rosana AR, Orata FD, Reiz B, Zheng J, et al. Bacillus amyloliquefaciens ssp. plantarum F11 isolated from Algerian salty lake as a source of biosurfactants and bioactive lipopeptides. FEMS Microbiol Lett. 2017;365:fnx248

13. Sumi CD, Yang BW, Yeo IC, Hahm YT. Antimicrobial peptides of the genus Bacillus: a new era for antibiotics. Can J Microbiol. 2014;61:93-103.

14. Baumann L, Okamoto K, Unterman BM, Lynch MJ, Baumann P. Phenotypic characterization of Bacillus thuringiensis and Bacillus cereus. J Invertebr Pathol. 1984;44:329-41.

15. Barjac H, Frachon E. Classification of Bacillus thuringiensis strains. BioControl. 1990:35:233-40.

16. Gibbons NE, Murray RG. Proposals concerning the higher taxa of bacteria. Int J Syst Evol Microbiol. 1978;28:1-6.

17. West AW, Burges H, Dixon TJ, Wyborn CH. Survival of Bacillus thuringiensis and Bacillus cereus spore inocula in soil: effects of $\mathrm{pH}$, moisture, nutrient availability and indigenous microorganisms. Soil Biol Biochem. 1985;17:657-65.

18. Ye W, Zhu L, Liu Y, Crickmore N, Peng D, Ruan L, Sun M. Mining new crystal protein genes from Bacillus thuringiensis on the basis of mixed plasmidenriched genome sequencing and a computational pipeline. Appl Environ Microbiol. 2012:78:4795-801.

19. Helgason E, Økstad OA, Caugant DA, Johansen HA, Fouet A, Mock M, et al. Bacillus anthracis, Bacillus cereus, and Bacillus thuringiensis-one species on the basis of genetic evidence. Appl Environ Microbiol. 2000;66:2627-30.

20. Nakamura LK, Roberts MS, Cohan FM. Relationship of Bacillus subtilis clades associated with strains 168 and W23: a proposal for Bacillus subtilis subsp. subtilis subsp. nov. and Bacillus subtilis subsp. spizizenii subsp. nov. Int J Syst Bacteriol. 1999:49:1211-5.

21. Field D, Garrity G, Gray T, Morrison N, Selengut J, Sterk P, et al. The minimum information about a genome sequence (MIGS) specification. Nat Biotechnol. 2008;26:541-7.

22. Rosana AR, Chamot D, Owttrim GW. Autoregulation of RNA helicase expression in response to temperature stress in Synechocystis sp. PCC 6803. PLoS One. 2012:7:e48683.

23. Tatusova T, DiCuccio M, Badretdin A, Chetvernin V, Nawrocki EP, Zaslavsky L, et al. NCBI prokaryotic genome annotation pipeline. Nucleic Acids Res. 2016; 44:6614-24

24. Markowitz VM, Chen IM, Palaniappan K, Chu K, Szeto E, Pillay M, et al. IMG 4 version of the integrated microbial genomes comparative analysis system. Nucleic Acids Res. 2013:42:D560-7.

25. Hyatt $D$, Chen GL, LoCascio PF, Land ML, Larimer FW, Hauser LJ. Prodigal: prokaryotic gene recognition and translation initiation site identification. BMC Bioinformatics. 2010;11:119.

26. Aziz RK, Bartels D, Best AA, DeJongh M, Disz T, Edwards RA, et al. The RAST server: rapid annotations using subsystems technology. BMC Genomics. 2008;9:75.

27. Van Domselaar GH, Stothard P, Shrivastava S, Cruz JA, Guo A, Dong X, et al. BASys: a web server for automated bacterial genome annotation. Nucleic Acids Res. 2005;33:W455-9.

28. Grissa I, Vergnaud G, Pourcel C. CRISPRFinder: a web tool to identify clustered regularly interspaced short palindromic repeats. Nucleic Acids Res. 2007;35:W52-7.

29. Galardini M, Biondi EG, Bazzicalupo M, Mengoni A. CONTIGuator: a bacterial genomes finishing tool for structural insights on draft genomes. Source Code Biol Med. 2011;6:11.
30. Bosi E, Donati B, Galardini M, Brunetti S, Sagot MF, Lió P, et al. MeDuSa: a multi-draft based scaffolder. Bioinformatics. 2015;31:2443-51.

31. Grant JR, Stothard P. The CGView server: a comparative genomics tool for circular genomes. Nucleic Acids Res. 2008;36:W181-4.

32. Varghese NJ, Mukherjee S, Ivanova N, Konstantinidis KT, Mavrommatis K, Kyrpides NC, et al. Microbial species delineation using whole genome sequences. Nucleic Acids Res. 2015;43(14):6761-71.

33. Meier-Kolthoff JP, Auch AF, Klenk HP, Göker M. Genome sequence-based species delimitation with confidence intervals and improved distance functions. BMC Bioinformatics. 2013;14:60.

34. He J, Wang J, Yin W, Shao X, Zheng H, Li M, et al. Complete genome sequence of Bacillus thuringiensis subsp. chinensis strain CT-43. J Bacteriol. 2011;193:3407-8.

35. Murawska E, Fiedoruk K, Bideshi DK, Swiecicka I. Complete genome sequence of Bacillus thuringiensis subsp. thuringiensis strain IS5056, an isolate highly toxic to Trichoplusia. Genome Announce. 2013;1:e00108-13.

36. Wang P, Zhang C, Guo M, Guo S, Zhu Y, Zheng J, et al. Complete genome sequence of Bacillus thuringiensis YBT-1518, a typical strain with high toxicity to nematodes. J Biotechnol. 2014;171:1-2.

37. Schleifer KH, Kraus J, Dvorak C, Kilpper-Bälz R, Collins MD, Fischer W. Transfer of Streptococcus lactis and related streptococci to the genus Lactococcus gen. Nov. Syst Appl Microbiol. 1985;6:183-95.

38. Schink B, Pfenning N. In Validation List no. 20. Validation of the publication of new names and new combinations previously effectively published outside the IJSB. Int J Syst Bacteriol. 1986;36:354-56.

39. Collins MD, Farrow JAE, Phillips BA, Ferusu S, Jones D. Classification of Lactobacillus divergens, Lactobacillus piscicola, and some catalase-negative asporogenous, rod-shaped bacteria from poultry in a new genus, Carnobacterium. Int J Syst Bacteriol. 1987;37:310-6.

40. Le Minor L, Popoff MY. Request for an opinion. Designation of Salmonella enterica sp. nov., nom. Rev., as the type and only species of the genus Salmonella. Int J Syst Bacteriol. 1987:37:465-8.

41. Cohn F. Untersuchungen über Bakterien. Beiträge zur Biologie der Pflanzen. 1872;1:127-224.

42. Skerman VBD, McGowan V, Sneath PHA. Approved lists of bacterial names Int J Syst Bacteriol. 1980;30:225-420.

43. Castellani A, Chalmers AJ. Genus Escherichia Castellani and Chalmers. Manual Trop Med. 1918;1919:941-3.

44. Migula W. Pseudomonas aeruginosa (Schröter) Mig. System der Bakterien. 1900;2:884-5

45. Schleifer KH, Kilpper-Bälz R. Transfer of Streptococcus faecalis and Streptococcus faecium to the genus Enterococcus nom. Rev. as Enterococcus faecalis comb. nov. and Enterococcus faecium comb. nov. Int J Syst Bacteriol. 1984;34:31-34.

46. Silo-Suh LA, Stabb EV, Raffel SJ, Handelsman J. Target range of zwittermicin a, an aminopolyol antibiotic from Bacillus cereus. Curr Microbiol. 1998:37:6-11.

47. Emmert EA, Klimowicz AK, Thomas MG, Handelsman J. Genetics of zwittermicin a production by Bacillus cereus. Appl Environ Microbiol. 2004; 70:104-13.

48. Koppisch AT, Dhungana S, Hill KK, Boukhalfa H, Heine HS, Colip LA, et al. Petrobactin is produced by both pathogenic and non-pathogenic isolates of the Bacillus cereus group of bacteria. Biometals. 2008:21:581-9.

49. Wilson MK, Abergel RJ, Arceneaux JE, Raymond KN, Byers BR. Temporal production of the two Bacillus anthracis siderophores, petrobactin and bacillibactin. Biometals. 2010;23:129.

50. Frankland GC, Frankland PF. Studies on some new microorganisms obtained from air. Philos Trans R Soc Lond Ser B Biol Sci. 1887;178:257-87.

51. Bertelli C, Laird MR, Williams KP, Simon Fraser University Research Computing Group, Lau BY, Hoad G, et al. IslandViewer 4: expanded prediction of genomic islands for larger-scale datasets. Nucleic Acids Res. 2017:45:W30-5.

52. Arndt D, Grant JR, Marcu A, Sajed T, Pon A, Liang Y, Wishart DS. PHASTER: a better, faster version of the PHAST phage search tool. Nucleic Acids Res. 2016;44:W16-21

53. Woese CR, Kandler O, Wheelis ML. Towards a natural system of organisms: proposal for the domains archaea, bacteria, and Eucarya. Proc Natl Acad Sci U S A. 1990:87(12):4576-9.

54. Validation EJ, No L. 132. List of new names and new combinations previously effectively, but not validly, published. Int J Syst Evol Microbiol. 2010;60:469-72 
55. Ludwig W, Schleifer KH, Whitman WB. Class I. Bacilliclass nov. In: De Vos P, Garrity G, Jones D, Krieg NR, Ludwig W, et al., editors. Bergey's Manual of Systematic Bacteriology. New York: Springer-Verlag; 2009. p. 19-20.

56. Prévot AR. In: Hauderoy P, Ehringer G, Guillot G, Magrou J, Prévot AR, Rosset $D$, Urbain A, editors. Dictionnaire des Bactéries Pathogènes. Paris: Masson et Cie; 1953. p. 1-692.

57. Fischer A. Untersuchungen über bakterien. Jahrbücher für Wissenschaftliche Botanik. 1895;27:1-163.

58. Berliner E. Über die Schlaffsucht der Mehlmottenraupe (Ephestia kühniella Zell.) und ihren Erreger Bacillus thuringiensis n. sp. J Appl Entomol. 1915;2: 29-56.

59. Vilas-Boas GT, Peruca AP, Arantes OM. Biology and taxonomy of Bacillus cereus, Bacillus anthracis, and Bacillus thuringiensis. Can J Microbiol. 2007;53: 673-87.

60. Schnepf E, Crickmore NV, Van Rie J, Lereclus D, Baum J, Feitelson J, et al. Bacillus thuringiensis and its pesticidal crystal proteins. Microbiol Molec Biol Rev. 1998:62:775-806.

61. Ashburner M, Ball CA, Blake JA, Botstein D, Butler H, Cherry JM, et al. Gene ontology: tool for the unification of biology. Nat Genet. 2000;25:25-9.

Ready to submit your research? Choose BMC and benefit from:

- fast, convenient online submission

- thorough peer review by experienced researchers in your field

- rapid publication on acceptance

- support for research data, including large and complex data types

- gold Open Access which fosters wider collaboration and increased citations

- maximum visibility for your research: over $100 \mathrm{M}$ website views per year

At $\mathrm{BMC}$, research is always in progress.

Learn more biomedcentral.com/submissions 